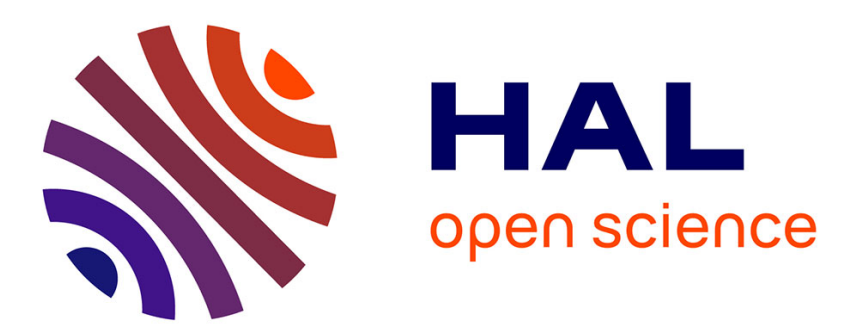

\title{
( TaC/Ta2C) bilayer formed on carburized and annealed tantalum; development of a numerical growth model
}

\author{
Laurent Carette, Philippe Jacquet, Dominique Cotton, Vincent Vignal,
} Sébastien Faure

\section{To cite this version:}

Laurent Carette, Philippe Jacquet, Dominique Cotton, Vincent Vignal, Sébastien Faure. (TaC/Ta2C) bilayer formed on carburized and annealed tantalum; development of a numerical growth model. Applied Surface Science, 2019, 467-468, pp.84-88. 10.1016/j.apsusc.2018.10.142 . hal-01940857

\section{HAL Id: hal-01940857 \\ https://hal.science/hal-01940857}

Submitted on 20 Dec 2018

HAL is a multi-disciplinary open access archive for the deposit and dissemination of scientific research documents, whether they are published or not. The documents may come from teaching and research institutions in France or abroad, or from public or private research centers.
L'archive ouverte pluridisciplinaire HAL, est destinée au dépôt et à la diffusion de documents scientifiques de niveau recherche, publiés ou non, émanant des établissements d'enseignement et de recherche français ou étrangers, des laboratoires publics ou privés. 


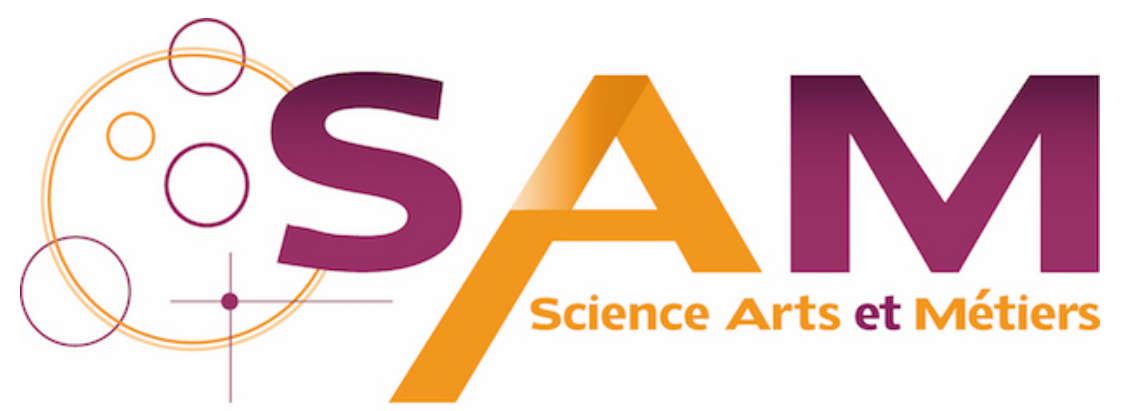

Archive Ouverte - Open Repository

\section{Science Arts \& Métiers (SAM)}

is an open access repository that collects the work of Arts et Métiers ParisTech researchers and makes it freely available over the web where possible.

This is an author-deposited version published in: https://sam.ensam.eu Handle ID: .http://hdl.handle.net/10985/14058

\section{To cite this version :}

Laurent CARETTE, Philippe JACQUET, Dominique COTTON, Vincent VIGNAL, Sébastien FAURE - (TaC/Ta2C) bilayer formed on carburized and annealed tantalum; development of a numerical growth model - Applied Surface Science - Vol. 467-468, p.84-88 - 2019 
Full Length Article

\title{
$\left(\mathrm{TaC} / \mathrm{Ta}_{2} \mathrm{C}\right)$ bilayer formed on carburized and annealed tantalum; development of a numerical growth model
}

\author{
Laurent Carette $^{\mathrm{a}, \mathrm{b}, \mathrm{c}, \mathrm{d}, *}$, Philippe Jacquet ${ }^{\mathrm{b}, \mathrm{d}}$, Dominique Cotton ${ }^{\mathrm{d}}$, Vincent Vignal ${ }^{\mathrm{c}}$, Sébastien Faure ${ }^{\mathrm{a}}$ \\ ${ }^{\text {a }}$ CEA, DAM, VALDUC, F-21100 Is-sur-Tille, France \\ ${ }^{\mathrm{b}}$ Université de Lyon, ECAM Lyon, INSA-Lyon, LabECAM, F-69005 Lyon, France \\ ' ICB, UMR 6303 CNRS - Université Bourgogne Franche Comté (UBFC), BP 47870, 21078 Dijon Cedex, France \\ d LaBoMaP, Arts et Métiers ParisTech, 71250 Cluny, France
}

A R T I C L E I N F O

\section{Keywords:}

Tantalum

$\mathrm{TaC}$

$\mathrm{Ta}_{2} \mathrm{C}$

Diffusion

Carburizing

Modeling

\begin{abstract}
A B S T R A C T
This paper describes a model developed to simulate the evolution of carbide layers $\left(\mathrm{TaC} / \mathrm{Ta}_{2} \mathrm{C}\right)$ formed during carburizing and annealing treatments of tantalum. The model is based on a parabolic evolution of the layer thickness during the growth, and on the carbon conservation during the annealing. In order to validate this model a MATLAB ${ }^{\circledR}$ program was developed. It enables the prediction of the evolution of the tantalum carbide layers (nature and thickness) for a desired treatment defined by a temperature, a carburizing and an annealing duration.
\end{abstract}

\section{Introduction}

Carburizing is a thermochemical treatment which increases the carbon concentration of a metallic surface in order to improve its properties such as hardness. The process used here for carburizing is described in a recent patent [1]. The carburizing gas is ethylene $\left(\mathrm{C}_{2} \mathrm{H}_{4}\right)$. It is introduced continuously inside the furnace with a controlled flow while a vacuum pump maintains a vacuum level of a few millibars. The carburizing temperature is set in a domain where the diffusion coefficients and the solubility of carbon in tantalum are known [2].

The process contains two steps; firstly an enrichment with carbon and secondly a diffusion sequence. Enrichment steps have already been studied and simulated in the literature for similar systems $\left(\mathrm{FeB} / \mathrm{Fe}_{2} \mathrm{~B}\right.$, $\mathrm{Fe}_{2-3} \mathrm{~N} / \mathrm{Fe}_{4} \mathrm{~N}$ ) [3-6] and for tantalum $[7,2,8]$. However, the simulation of the annealing step for a bilayer system is not developed in these studies. The purpose of the model presented in this paper is to define the duration of each step in order to obtain the desired microstructure.

The model, developed with MATLAB ${ }^{\circledR}$ software, is composed of several steps. Carburizing consists of a carbon enrichment phase (Step 1) during which two carbide layers appear: $\mathrm{TaC}$ on the surface and $\mathrm{Ta}_{2} \mathrm{C}$ below. Then, annealing, which is divided into two carbon diffusion steps, leads firstly to the disappearance of the TaC layer and to the growth of the $\mathrm{Ta}_{2} \mathrm{C}$ one (Step 2). Secondly, annealing leads to the disappearance of the $\mathrm{Ta}_{2} \mathrm{C}$ layer (Step 3). After the treatment, the cooling to room temperature changes the carbon solubility in tantalum, leading to a $\mathrm{Ta}_{2} \mathrm{C}$ precipitate layer in carbon saturated tantalum.

\section{Model assumptions}

In this model, the following assumptions are made:

- The carbon flow on the surface is sufficient to saturate the surface and obtain TaC.

- The kinetics are driven by the growth coefficient of the layers and carbon diffusion coefficient.

- Layer evolutions are due to the carbon diffusion perpendicularly to the plane surface of the sample.

- Carbon diffusion coefficients are independent of the carbon concentration; in each layer they follow an Arrhenius law.

- The temperature is supposed to be uniform and constant throughout the sample.

- Layer thicknesses are small compared to the sample: the carbon concentration of the heart of the sample is zero.

- When the carbon source of a layer disappears, the time needed to homogenize the carbon concentration in the layer is supposed to be zero.

- The volume variation is neglected.

- Porosity, roughness and material defects are not taken into account. 


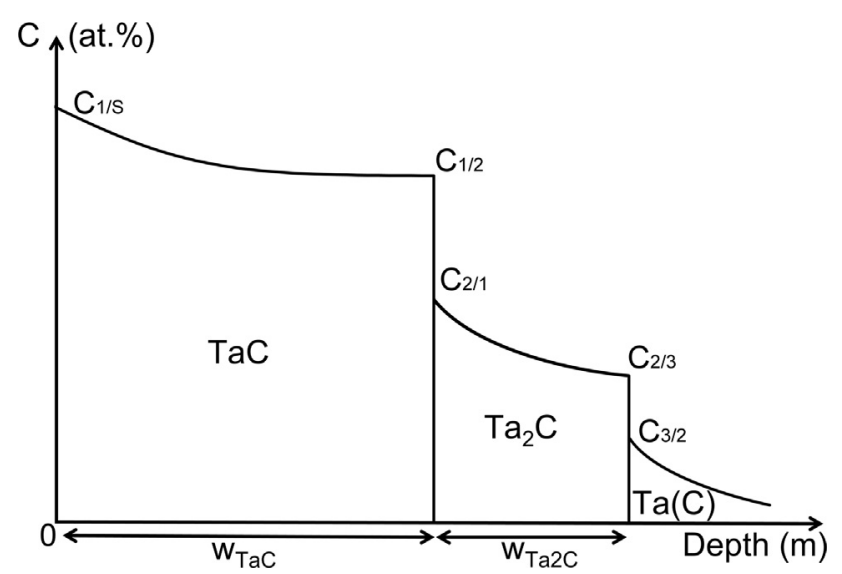

Fig. 1. Carbon profile after a carburizing process: Step 1 corresponding to carbon enrichment

\section{Layer evolution model}

If the carburizing cycle of tantalum is well set, a microstructure with three different layers as presented in Fig. 1 is obtained.

For all following equations, the index $i$ indicates to which zone the parameter refers: $i=1$ for the TaC layer, $i=2$ for the $\mathrm{Ta}_{2} \mathrm{C}$ layer and $i=3$ for the carbon solid solution in tantalum matrix.

\subsection{Carbon enrichment phase (Step 1)}

Enrichment phases have already been studied in the literature for similar systems like $\mathrm{FeB}$ and $\mathrm{FeB}_{2}$ for boriding [3,4], $\mathrm{Fe}_{2-3} \mathrm{~N}$ and $\mathrm{Fe}_{4} \mathrm{~N}$ for nitriding $[5,6]$ and also for carburizing $\mathrm{TaC}$ and $\mathrm{Ta}_{2} \mathrm{C}[7,2,8]$. During carburizing, the calculation of layer thicknesses depending on the layer growth coefficient and on the treatment duration is given by Eq. (1)

$w_{i}=\sqrt{k_{i} \cdot t_{c a r b}}$

With $w_{i}$ the layer thickness (m), $t_{c a r b}$ the carburizing duration (s) and $k_{i}$ the layer growth coefficient $\left(\mathrm{m}^{2} \cdot \mathrm{s}^{-1}\right), i=(1,2)$.

In each phase the carbon concentration is a function of the depth and responds to Eq. (2).

$c\left(x_{i}, t_{c a r b}\right)=A_{i}+B_{i} \cdot \operatorname{erf}\left(\frac{x_{i}}{2 \sqrt{D_{i} \cdot t_{c a r b}}}\right)$

With $c\left(x_{i}, t_{\text {carb }}\right)$ the carbon concentration (at.\%) at the depth $x_{i}$ (m) for the carburizing duration $t_{\text {carb }}$ (s), $D_{i}$ the carbon diffusion coefficient $\left(\mathrm{m}^{2} \cdot \mathrm{s}^{-1}\right)$, and, $A_{i}$ and $B_{i}$ two constants (at.\%). $i=(1,2,3)$.

If layer thicknesses and their limit concentrations are known (Table 1 according to Fig. 1), it is possible to calculate the carbon concentration as a function of depth. Integrating concentrations over the entire profile, the total amount of carbon diffused in the sample $I_{\text {tot }}$ is obtained. During the following diffusion phases (annealing), this global quantity of carbon will be conserved inside the sample.

\subsection{Carbon diffusion phases (Steps 2 and 3)}

\subsubsection{Carbon profile in the tantalum matrix}

During the annealing, as long as $\mathrm{TaC}$ and $\mathrm{Ta}_{2} \mathrm{C}$ layers are not

Table 1

Limit concentrations of carbon in each phase at $1600^{\circ} \mathrm{C}$ according to references [9-11].

\begin{tabular}{llllll}
\hline & $C_{1 / \mathrm{s}}$ & $\boldsymbol{C}_{1 / 2}$ & $\boldsymbol{C}_{2 / 1}$ & $\boldsymbol{C}_{2 / 3}$ & $\boldsymbol{C}_{3 / 2}$ \\
\hline Values (at.\%) & 50 & 42.5 & 33.3 & 29.0 & 0.40 \\
\hline
\end{tabular}

consumed, the mobile interface $\mathrm{Ta}_{2} \mathrm{C} / \mathrm{Ta}(\mathrm{C})$ can be considered as the carbon source which enriches the tantalum matrix $\mathrm{Ta}(\mathrm{C})$. The new carbon profile in the matrix responds to an expression similar to the Eq. (2), described in Eq. (3) with a treatment durationt $t_{c a r b}+t_{a n}$ :

$c\left(x_{3}, t_{c a r b}+t_{a n}\right)=A_{3}+B_{3} \cdot \operatorname{erf}\left(\frac{x_{3}}{2 \sqrt{D_{3} \cdot\left(t_{c a r b}+t_{a n}\right)}}\right)$

$I_{3}^{\prime}$ is the integral of the concentration of carbon in solid solution in the tantalum matrix. Its calculation leads to two possible cases.

- If $I_{3}{ }_{3}<I_{\text {tot }}$, at least one carbide layer remains and its thickness can be calculated with the model.

- If not, the two carbide layers are consumed.

\subsubsection{Carbon profile in carbide layers if $I_{3}^{\prime}<I_{\text {tot }}$}

The model assumes that as soon as enrichment stops, the carbon concentration in the $\mathrm{TaC}$ layer instantaneously homogenizes to its minimum value $\mathrm{C}_{1 / 2}$. The same is also assumed for the $\mathrm{Ta}_{2} \mathrm{C}$ layer: the carbon concentration takes the value $\mathrm{C}_{2 / 3}$ after the disappearance of the upper layer. Carbon profiles in Fig. 2 step 2 and step 3 illustrate these hypotheses.

Cotton [12] showed that as long as the TaC layer is not totally consumed, the depth $w_{\text {TaC+Ta2C }}^{\prime}$ of the interface $\mathrm{Ta}_{2} \mathrm{C} / \mathrm{Ta}(\mathrm{C})$ follows the same law as during carburizing. This leads to Eq. (4).

$w_{T a C+T a 2 C}^{\prime}=w_{T a C}^{\prime}+w_{T a 2 C}^{\prime}=\sqrt{t_{c a r b}+t_{a n}} \times\left(\sqrt{k_{T a C}}+\sqrt{k_{T a 2 C}}\right)$

For a given treatment duration, the program precisely determines the position of $\mathrm{Ta}_{2} \mathrm{C} / \mathrm{Ta}(\mathrm{C})$ interface according to Fig. 2 step 2 and to the Eq. (4). The thickness of the TaC layer is initialized to that obtain after carburizing.

Then the program iteratively decreases the depth of $\mathrm{TaC} / \mathrm{Ta}_{2} \mathrm{C}$ interface until the integral of carbon concentrations in the new profile is equal to the integral $I_{t o t}$ after carburizing. At each iteration $A_{2}$ and $B_{2}$ constants of the Eq. (2) for $i=2$ and $t=t_{\text {carb }}+t_{a n}$ are recalculated in order to adjust the carbon profile. If the integrals are not balanced before the TaC layer totally disappears, the profile changes to the configuration of Fig. 2 step 3. The program therefore gradually reduces the thickness of $\mathrm{Ta}_{2} \mathrm{C}$ in turn until balancing integrals.

\section{Results and discussion}

In the literature, the values of carbon diffusion coefficient in tantalum differ slightly from one to another [12-16]: this is probably due to the dependence of the coefficient with the material microstructure (grain size, hardening...) which is not described in these publications. The carbon diffusion coefficient in tantalum calculated by Cotton [12] by inverse analysis of the depth of $\mathrm{Ta}_{2} \mathrm{C}$ precipitates after cooling; its value at $1600{ }^{\circ} \mathrm{C}$ is $D_{c}^{T a}=6.02 \cdot 10^{-12} \mathrm{~m}^{2} / \mathrm{s}$. However, at the same temperature, the coefficient calculated by Son et al. [13] is four times greater $\left(23.37 \cdot 10^{-12} \mathrm{~m}^{2} / \mathrm{s}\right)$. For example, for an enrichment of $600 \mathrm{~s}$, $228 \mathrm{~min}$ of annealing are necessary for the disappearance of $\mathrm{TaC}$ and $\mathrm{Ta}_{2} \mathrm{C}$ layers with Cotton's diffusion coefficient while only $80 \mathrm{~min}$ are necessary with Son's coefficient. This highlights the importance of choosing appropriate data. For the present work, the values of Cotton [12] are chosen because they were calculated with the same carburizing process as that used for experiment. Moreover, the model uses a minimum carbon concentration threshold to calculate the profile of carbon in solid solution in tantalum. The value of this threshold is 0.0075 at.\% because the sensitivity study shows that considering lower thresholds changes annealing time for layers disappearance by less than one percent.

In order to execute the model, the chosen values set for the Arrhenius laws leading to carbon diffusion and layer growth coefficients are referenced in Table 2. By integrating these values into the model and by setting a carburizing time, the program can return the evolution of the layer thicknesses and the surface phase during an 


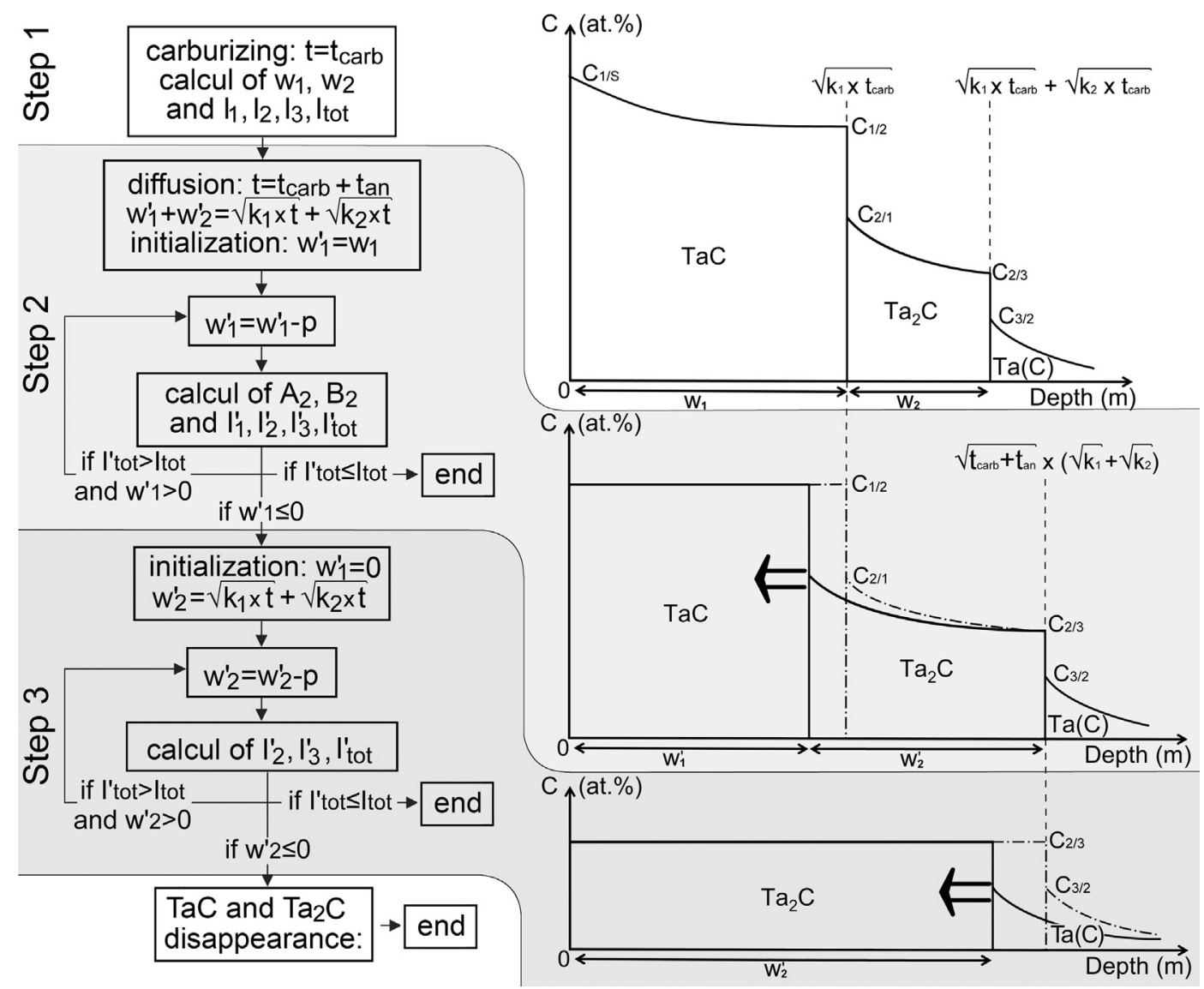

Fig. 2. Schematization of the model algorithm.

Table 2

Carbon diffusion coefficient and layer growth coefficients for each phase from $1400{ }^{\circ} \mathrm{C}$ to $2000^{\circ} \mathrm{C}$.

\begin{tabular}{cllll}
\hline & Ta $(\mathrm{C})$ & $\mathrm{Ta}_{2} \mathrm{C}$ & $\mathrm{TaC}$ \\
\hline $\begin{array}{c}\text { Carbon } \\
\text { diffusion }\end{array}$ & $D_{o}\left(\mathrm{~m}^{2} \cdot \mathrm{s}^{-1}\right)$ & $1.94 \cdot 10^{-6}[12]$ & $1.27 \cdot 10^{-6}[7]$ & $1.94 \cdot 10^{-6}[7]$ \\
coefficients & $E\left(\mathrm{~J} \cdot \mathrm{mol}^{-1}\right)$ & $197.5 \cdot 10^{3}[12]$ & $298.1 \cdot 10^{3}[7]$ & $324.9 \cdot 10^{3}[7]$ \\
& & & & \\
Layer growth & $\boldsymbol{k}_{\boldsymbol{o}}\left(\mu \mathrm{m}^{2} \cdot \mathrm{h}^{-1}\right)$ & - & $63.25 \cdot 10^{3}[12]$ & $201.6 \cdot 10^{3}[12]$ \\
$\quad$ coefficients & $E\left(\mathrm{~J} \cdot \mathrm{mol}^{-1}\right)$ & - & $168.1 \cdot 10^{3}[12]$ & $141.2 \cdot 10^{3}[12]$ \\
\hline
\end{tabular}

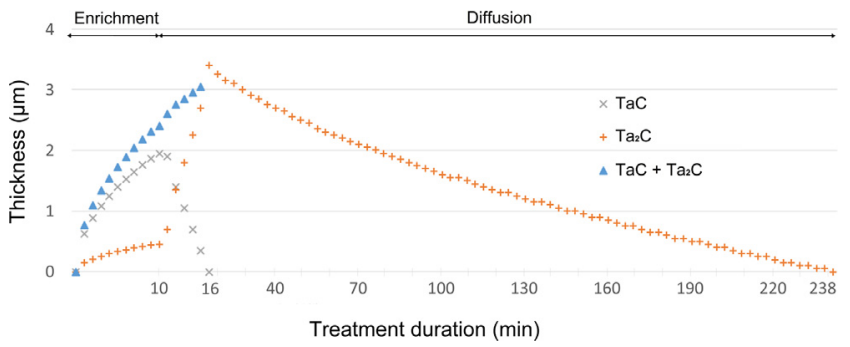

Fig. 3. Evolution of layer thicknesses during a carbon enrichment of $10 \mathrm{~min}$ followed by annealing at $1600{ }^{\circ} \mathrm{C}$.

annealing. For example, for 10 min carburizing duration Fig. 3 shows the microstructure as a function of the depth and of the annealing time. This makes it possible to choose the time of treatment in order to have a desired surface microstructure.

Fig. 3 shows that after $10 \mathrm{~min}$ of enrichment at $1600^{\circ} \mathrm{C}$ a bilayer is obtained: $2 \mu \mathrm{m}$ of $\mathrm{TaC}$ on the surface and $0.5 \mu \mathrm{m}$ of $\mathrm{Ta}_{2} \mathrm{C}$ below. After $6 \mathrm{~min}$ of annealing, the surface $\mathrm{TaC}$ layer completely disappears in

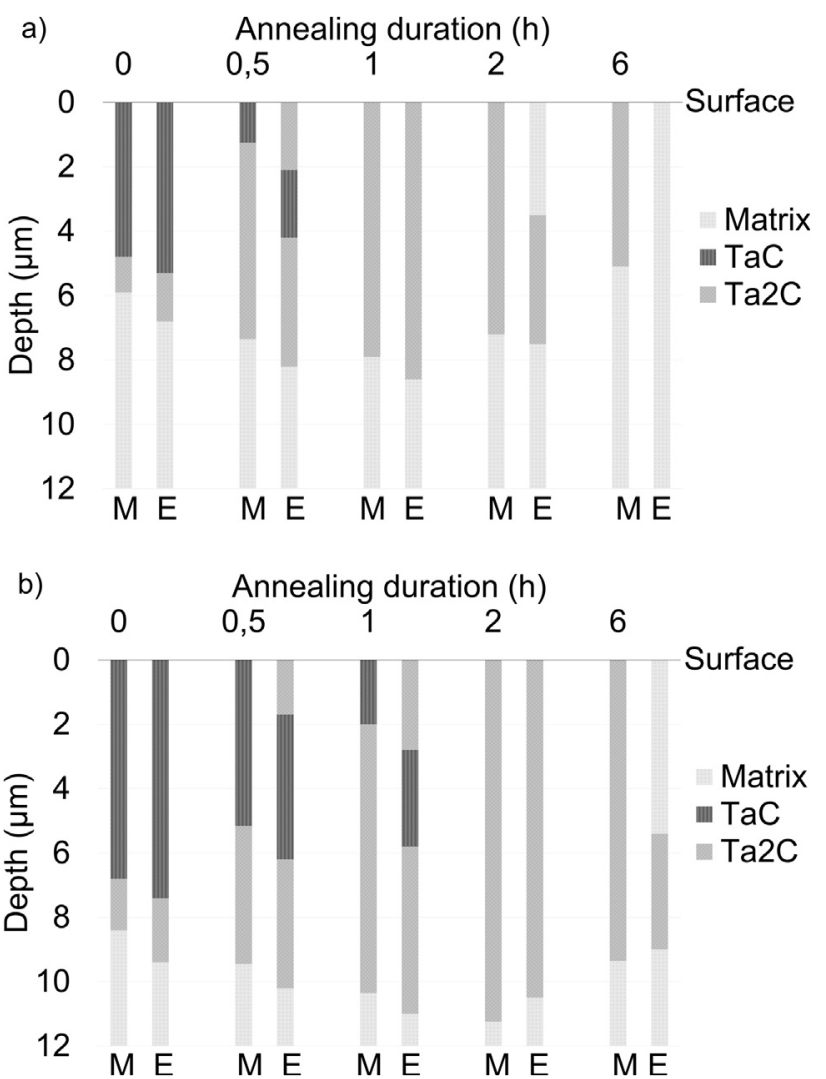

Fig. 4. Confrontation of the model (M) with the experiment (E): for carburizing of $1 \mathrm{~h} \mathrm{(a)}$ and $2 \mathrm{~h}(\mathrm{~b})$. 

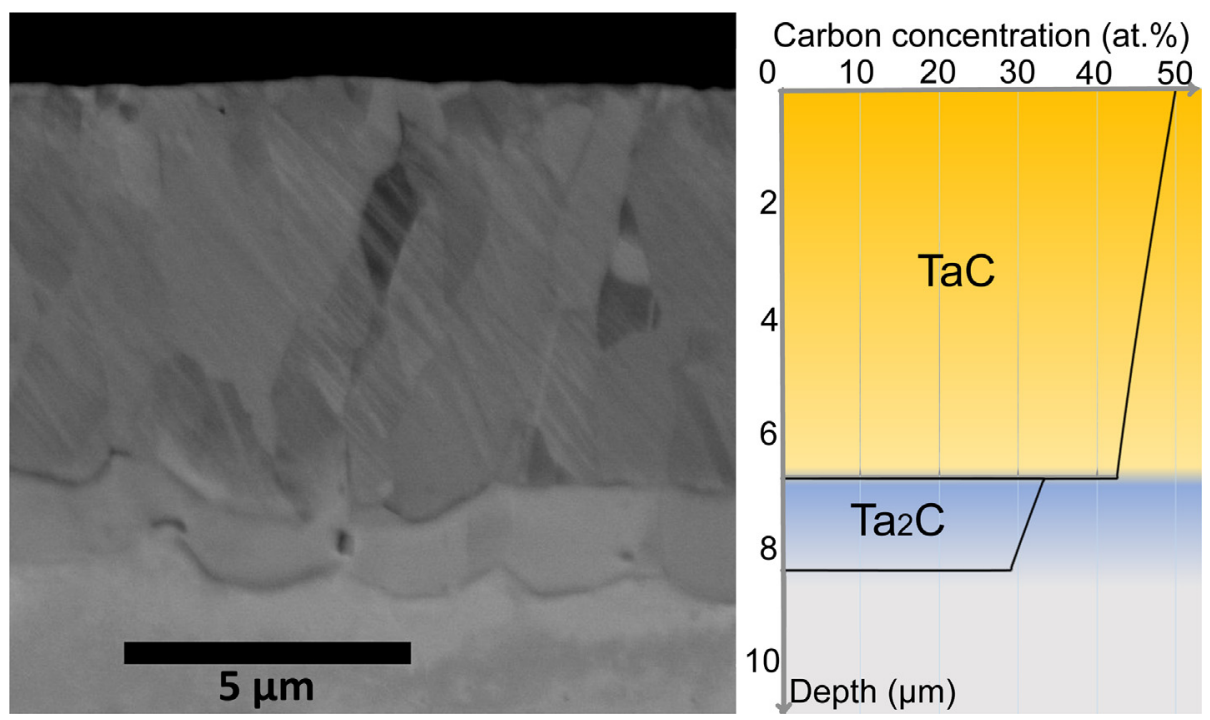

Fig. 5. Tantalum carburized $2 \mathrm{~h}$ at $1600{ }^{\circ} \mathrm{C}$, SEM image (left); model prediction (right).

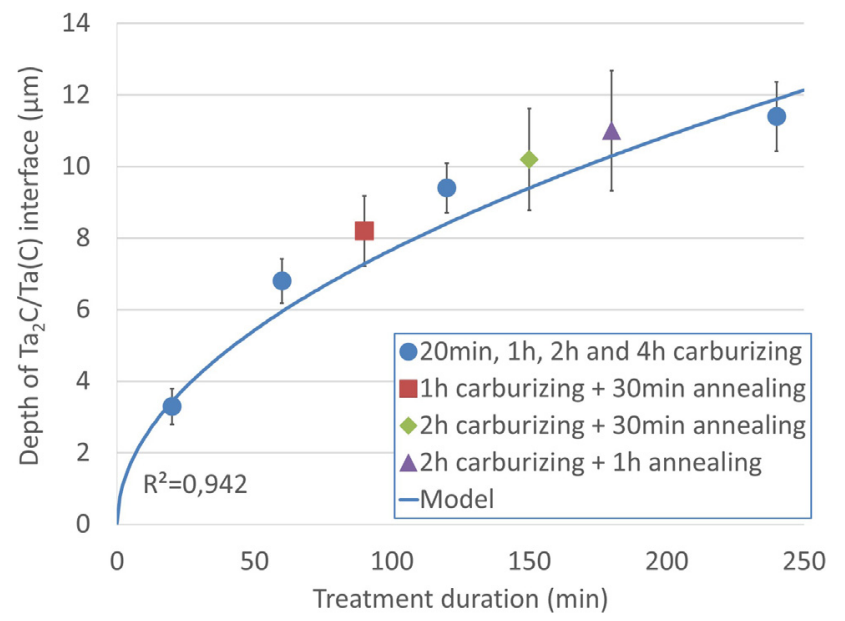

Fig. 6. Depth of $\mathrm{Ta}_{2} \mathrm{C} / \mathrm{Ta}(\mathrm{C})$ interface for carburized and annealed samples containing a TaC layer.

favour of a $3.4 \mu \mathrm{m} \mathrm{Ta}{ }_{2} \mathrm{C}$ layer. After $222 \mathrm{~min}$ of additional annealing the $\mathrm{Ta}_{2} \mathrm{C}$ totally disappears leading to a tantalum matrix with carbon in solid solution. When cooling this microstructure, the solubility of carbon inside tantalum grains decreases and $\mathrm{Ta}_{2} \mathrm{C}$ precipitates appear inside the tantalum matrix.

However, in Fig. 3 during the diffusion step, at the moment of the total disappearance of the TaC layer, a discontinuity is observed for the thickness of $\mathrm{Ta}_{2} \mathrm{C}$ layer. This discontinuity is due to the hypothesis which states that the homogenization of the carbon concentration is instantaneous in the $\mathrm{Ta}_{2} \mathrm{C}$ layer when the upper layer totally disappears.

In Fig. 4 and Fig. 5, the model is compared to experimental results obtained by Cotton [12] after $1 \mathrm{~h}$ of carburizing (Fig. 4a), and $2 \mathrm{~h}$ of carburizing (Fig. 5 and Fig. 4b). The total thickness of layers predicted with the model is in good agreement with the tests of Cotton [12]. However, for the experiment, the presence of undesired decarburization on the surface was observed during annealing. This can be correlated with the layers disappearance faster than according to the model. In Fig. 6, the depth of the $\mathrm{Ta}_{2} \mathrm{C} / \mathrm{Ta}(\mathrm{C})$ interface is plot versus the treatment duration for samples which contain a TaC layer (only carburizing or carburizing and annealing). Despite the surface decarburization, Fig. 6 shows that the TaC permits the enrichment of the underlying layer, and the position of the $\mathrm{Ta}_{2} \mathrm{C} / \mathrm{Ta}(\mathrm{C})$ interface follow the law described with
Eq. (4). Finally, in spite of the decarburization, there is a good correlation between the theoretical model and the experience.

\section{Conclusion}

- The evolution of $\mathrm{TaC}$ and $\mathrm{Ta}_{2} \mathrm{C}$ layers during carburizing and annealing is simulated with a model which firstly considers the layers growth coefficients and then the constant quantity of absorbed carbon in tantalum during the annealing.

- This model permits to adjust treatment duration in order to obtain a specific microstructure on the surface.

- The model gives thicknesses of carbide layers in good agreements with experimental results.

- The carbon diffusion coefficient in tantalum (depending on grain size, microstructure...) is a key parameter of the model. This parameter significantly differs in the literature. For this reason, the carbon diffusion coefficient has to be estimated prior carburizing and annealing treatment to take into account the state of the raw material.

- This model can be used for similar diffusion models with bilayers like steel boriding or nitriding.

\section{Acknowledgments}

The authors wish to thank CEA/DAM, ECAM Lyon and CNRS for the financial support of this research.

\section{Appendix A. Supplementary material}

Supplementary data to this article can be found online at https:// doi.org/10.1016/j.apsusc.2018.10.142.

\section{References}

[1] D. Cotton, S. Faure, P. Jacquet, V. Vignal, Process for treating a piece of tantalum or of a tantalum alloy, EP3109339A1, US20160376692 A1, 2016.

[2] W.F. Brizes, Diffusion of carbon in the carbides of tantalum, J. Nucl. Mater. 26 (1968) 227-231.

[3] M. Keddam, M. Kulka, N. Makuch, A. Pertek, L. Małdziński, A kinetic model for estimating the boron activation energies in the $\mathrm{FeB}$ and $\mathrm{Fe} 2 \mathrm{~B}$ layers during the gasboriding of Armco iron: Effect of boride incubation times, Appl. Surf. Sci. 298 (2014) 155-163.

[4] M. Keddam, Simulation of the growth kinetics of the (FeB/Fe2B) bilayer obtained on a borided stainless steel, Appl. Surf. Sci. 257 (6) (2011) 2004-2010.

[5] M. Keddam, M.E. Djeghlal, L. Barrallier, A diffusion model for simulation of bilayer growth (epsilon/gamma') of nitrided pure iron, Mater. Sci. Eng. A 378 (1-2 SPEC. 
ISS.) (2004) 475-478.

[6] M. Keddam, M.E. Djeghlal, L. Barrallier, E. Salhi, Computer simulation of nitrided layers growth for pure iron, Comput. Mater. Sci. 29 (1) (2004) 43-48.

[7] N.H. Krikorian, T.C. Wallace, R. Krohn, M.G. Bowman, The formation of carbide surfaces on tantalum and tantalum-tungsten alloys, Los Alamos National Laboratory, 1968.

[8] R. Resnick, R. Steinitz, L. Seigle, Determination of diffusivity of carbon in tantalum and columbium carbides by layer-growth measurements, Trans. Metall. Soc. AIME 233 (October) (1965) 1915-1918.

[9] R. Lesser, G. Brauer, Karbidphasen des Tantals, Zeitschrift für Met. 49 (1958) 622-626.

[10] A.I. Gusev, A.S. Kurlov, V.N. Lipatnikov, Atomic and vacancy ordering in carbide ZETA-Ta4C3-x $(0.28 \times 0.40)$ and phase equilibria in the Ta-C system, J. Solid State Chem. 180 (11) (2007) 3234-3246.
[11] G. Hörz, K. Lindenmaier, R. Klaiss, High-temperature solid solubility limit of carbon in niobium and tantalum, J. Less-Common Met. 35 (1974) 97-105.

[12] D. Cotton, Etude de formation d'hémicarbure de tantale (Ta2C) par l'intermédiaire d'un procédé de cémentation sous pression réduite, doctoral thesis Université de Bourgogne, 2015.

[13] P. Son, S. Ihara, M. Miyake, T. Sano, Diffusion of carbon in tantalum, J. Jpn. Inst Met. Mater. 30 (1966) 1137-1140.

[14] T.-S. Ké, Internal friction in the interstitial solid solutions of $\mathrm{C}$ and $\mathrm{O}$ in tantalum, Phys. Rev. 74 (1) (1948) 9-15.

[15] C.A. Wert, Measurements on the diffusion of interstitial atoms in BCC lattices, J Appl. Phys. 21 (11) (1950) 1196-1197.

[16] R.W. Powers, M.V. Doyle, Diffusion of interstitial solutes in the Group V transition metals, J. Appl. Phys. 30 (4) (1959) 514-524. 